\title{
Conditions stimulating neutral detergent fiber degradation by dosing branched-chain volatile fatty acids. II: Relation with solid passage rate and $\mathrm{pH}$ on neutral detergent fiber degradation and microbial function in continuous culture
}

\author{
Y. Roman-Garcia, ${ }^{1 *} \odot$ K. E. Mitchell, ${ }^{1} \oplus$ B. L. Denton, ${ }^{1} \odot$ C. Lee, ${ }^{2} \odot$ M. T. Socha, ${ }^{3} \odot$ B. A. Wenner, ${ }^{1} \odot$ \\ and J. L. Firkins ${ }^{1} \dagger$ () \\ ${ }^{1}$ Department of Animal Sciences, The Ohio State University, Columbus 43210 \\ ${ }^{2}$ Ohio Agricultural Research and Development Center, Wooster 44691 \\ ${ }^{3}$ Zinpro Corporation, Eden Prairie, MN 55344
}

\begin{abstract}
To support improving genetic potential for increased milk production, intake of digestible carbohydrate must also increase to provide digestible energy and microbial protein synthesis. We hypothesized that the provision of exogenous branched-chain volatile fatty acids (BCVFA) would improve both neutral detergent fiber (NDF) degradability and efficiency of microbial protein synthesis. However, BCVFA should be more beneficial with increasing efficiency of bacterial protein synthesis associated with increasing passage rate $\left(\mathrm{k}_{\mathrm{p}}\right)$. We also hypothesized that decreasing $\mathrm{pH}$ would increase the need for isobutyrate over 2-methylbutyrate. To study these effects independent from other sources of variation in vivo, we evaluated continuous cultures without (control) versus with BCVFA (0 vs. $2 \mathrm{mmol} / \mathrm{d}$ each of isobutyrate, isovalerate, and 2-methylbutyrate), low versus high $\mathrm{k}_{\mathrm{p}}$ of the particulate phase $(2.5$ vs. $5.0 \% / \mathrm{h})$, and high versus low $\mathrm{pH}$ (ranging from 6.3 to 6.8 diurnally vs. 5.7 to 6.2$)$ in a $2 \times 2 \times 2$ factorial arrangement of treatments. Diets were $50 \%$ forage pellets and $50 \%$ grain pellets administered twice daily. Without an interaction, NDF degradability tended to increase from 29.7 to $35.0 \%$ for main effects of control compared with BCVFA treatments. Provision of BCVFA increased methanogenesis, presumably resulting from improved NDF degradability. Decreasing pH decreased methane production. Total volatile fatty acid (VFA) and acetate production were decreased with increasing $k_{p}$, even though true organic matter degradability and bacterial nitrogen flow were not affected by treatments. Decreas-
\end{abstract}

\footnotetext{
Received February 19, 2021.

Accepted May 2, 2021.

* Current address: Cargill Animal Nutrition, Innovation Campus, Elk River, MN 55330.

†Corresponding author: firkins.1@osu.edu
}

ing $\mathrm{pH}$ decreased acetate but increased propionate and valerate production, probably resulting from a shift in bacterial taxa and associated VFA stoichiometry. Decreasing $\mathrm{pH}$ decreased isobutyrate and isovalerate production while increasing 2-methylbutyrate production on a net basis (subtracting doses). Supplementing BCVFA improved NDF degradability in continuous cultures administered moderate (15.4\%) crude protein diets (excluding urea in buffer) without major interactions with culture $\mathrm{pH}$ and $\mathrm{k}_{\mathrm{p}}$.

Key words: branched-chain volatile fatty acid, fiber degradation, rumen $\mathrm{pH}$, continuous culture

\section{INTRODUCTION}

Rumen-degraded carbohydrate and protein need to be provided in appropriate amounts to optimize the efficiency of microbial protein synthesis in the rumen and passage to the duodenum to optimize metabolizable protein supply while minimizing environmental nitrogen excretion (Firkins et al., 2007). Those authors explained that increasing ruminal passage rate, which is likely with increasing DMI by high-producing cows, should improve efficiency of microbial protein synthesis. To achieve this potential improvement, adequate supply of dietary preformed AA helps to increase the proportion of ATP derived from fermentation that is used for growth versus nongrowth ATP expenditure (Hackmann and Firkins, 2015a). Roman-Garcia et al. (2016) noted an important relationship between either isovalerate or isobutyrate with efficiency of microbial protein synthesis in a meta-analysis of rumen microbial outflow studies in dairy cattle; however, these effects need to be re-evaluated directly, because most studies used a procedure that allows isovalerate and 2-methylbutyrate to coelute. Therefore, our preliminary study evaluated different combinations of branched-chain AA (BCAA) or their deaminated and decarboxyl- 
ated products (i.e., branched-chain volatile fatty acids, BCVFA) in batch cultures of mixed rumen microbes (Roman-Garcia et al., 2021a). The BCAA were primarily converted to BCVFA, but the latter was more extensively assimilated into bacterial branched-chain fatty acids. The BCVFA are required growth factors for numerous strains of cellulolytic bacteria (Stewart et al., 1997), which are key to initiating colonization and optimizing degradability of fiber in the rumen (Gruninger et al., 2019).

Numerous dietary factors could influence ruminal BCVFA concentration (Firkins et al., 2006). Dosing BCVFA has increased efficiency of bacterial growth and substrate degradability in batch culture (Cummins and Papas, 1985; Gorosito et al., 1985; Mir et al., 1986). Individual or groups of BCVFA increased NDF degradability at $24 \mathrm{~h}$ of incubation in batch cultures of mixed rumen microbes, especially when orchardgrass was forage (Roman-Garcia et al., 2021a). Therein, we noted that either isovalerate or isobutyrate plus 2-methylbutyrate consistently improved NDF degradability. Continuous culture can derive total VFA production while measuring NDF degradability and microbial protein synthesis values that are more reflective of ruminal conditions than batch culture. Kone et al. (1989) reported that acetate and total VFA concentration increased when supplementing BCVFA in continuous cultures fed timothy hay and urea, but those authors did not assess NDF degradability or evaluate addition of starch as would be typical with dairy rations. Few other data are available on BCVFA supplementation of continuous cultures.

Decreasing $\mathrm{pH}$ below 6.0 might depress attachment by fibrolytic bacteria that are thought to benefit most from BCVFA (Hoover, 1986), although the $\mathrm{pH}$ probably is more detrimental to initial attachment (Mouriño et al., 2001). Decreased pH needs to be differentiated from $\mathrm{pH}$-independent differences related to decreasing forage-to-concentrate ratio (Firkins, 2010). Decreasing $\mathrm{pH}$ shifted VFA stoichiometry and decreased protein degradability (Calsamiglia et al., 2008; Wenner et al., 2017) and decreased efficiency of microbial protein synthesis (Wenner et al., 2017).

Because BCVFA are precursors for bacterial branched-chain fatty acids in membranes and BCAA in protein, BCVFA uptake likely increases with increasing bacterial growth rate. The efficiency of bacterial growth was increased by increasing particulate phase passage rate $\left(\mathbf{k}_{\mathbf{p}}\right)$ in continuous culture (Qiu et al., 2004; Wenner et al., 2017). In situations of high $\mathrm{k}_{\mathrm{p}}$ when bacterial growth rate might increase to maintain populations, BCVFA were hypothesized to assimilate more extensively into bacterial constituents; thus, the availability of primers and their concentration to com- pete with straight-chain primers for fatty acid synthesis might be limiting because of faster washout. Although an increased BCVFA requirement with increasing DMI has been speculated (Hoover, 1986), data are limiting to explain how ruminal $k_{p}$ influences BCVFA requirement by cellulolytics.

The objective of this study was to test for interactions in how decreasing $\mathrm{pH}$ and increasing $\mathrm{k}_{\mathrm{p}}$ affect the potential for exogenous BCVFA to improve NDF degradability and efficiency of bacterial protein synthesis. We hypothesized that increasing growth rate with faster $k_{p}$ would increase NDF degradability and efficiency of microbial protein synthesis, and BCVFA addition would help fibrolytic bacteria compete with more acid-tolerant bacteria to withstand periodic depressions in $\mathrm{pH}$.

\section{MATERIALS AND METHODS}

\section{Continuous Culture Operation}

Experimental Design and Treatments. In this study, 8 dual-flow continuous culture fermentors were used in an incomplete block design with 4 experimental periods. The 12-d period comprised $8 \mathrm{~d}$ of adjustment followed by $4 \mathrm{~d}$ of sampling. We tested a $2 \times 2 \times$ 2 factorial arrangement of 8 treatment combinations. Treatment factors were (1) control or BCVFA supplementation, (2) high $\mathrm{pH}$ (ranging from 6.3 to 6.8 ) or low $\mathrm{pH}$ (ranging from 5.7 to 6.2 ), and (3) low $(2.5 \% / \mathrm{h}$ ) or high $(5.0 \% / \mathrm{h})$ solids $\mathrm{k}_{\mathrm{p}}$. The BCVFA treatment included $2 \mathrm{mmol}$ each of isovalerate, isobutyrate, and 2-methylbutyrate dosed per day. Based on prior results (Roman-Garcia et al., 2021a), valerate was deemed unnecessary and not dosed.

Dose Estimation. When scaled to the largest fermentor volume $(1,920 \mathrm{~mL})$, our individual BCVFA doses from batch culture (Roman-Garcia et al., 2021a) would equal $1.9 \mathrm{mmol} / \mathrm{d}$. However, dose should be related to amount of substrate fed and VFA produced, not to a concentration that could be diluted simply by changing the volume of the buffer. Fowler et al. (2015) used similar conditions and noted treatment shifts in BCVFA production. Those authors reported an average of $180 \mathrm{mmol} / \mathrm{d}$ of total VFA in continuous cultures; total BCVFA averaged $4.7 \mathrm{mmol} / \mathrm{d}$ and had a maximum production of $5.6 \mathrm{mmol} / \mathrm{d}$. With the goal of at least doubling the amount of BCVFA to test our objectives, we dose $2 \mathrm{mmol} / \mathrm{d}$ of each BCVFA (i.e., $6.0 \mathrm{mmol} / \mathrm{d}$ total).

Continuous Culture Operation. At the beginning of each period, $8 \mathrm{~L}$ of rumen contents were manually sampled from 4 ruminally cannulated lactating Jersey cows fed a standard lactation diet averaging 35\% corn 
silage, $16 \%$ alfalfa hay, $22 \%$ ground corn, $8.8 \%$ wet brewers grains, $8.5 \%$ AminoPlus (AGP Ag Processing Inc.), $2.7 \%$ soybean meal, $2.1 \%$ soybean hulls, $1.4 \%$ Megalac (Church and Dwight), $0.5 \%$ dried molasses, and $3.0 \%$ of the remainder containing vitamins, minerals, and additives (no ionophores). Diet formulations averaged 17.1\% CP and 10.2\% RDP according to Spartan Dairy Ration Evaluator (Michigan State University, Lansing). Cows were housed according to Institutional Animal Care and Use Committee standards at the Waterman Dairy in Columbus, Ohio. Ruminal contents were rapidly squeezed through 2 layers of cheesecloth, and then liquid was placed in prewarmed, insulated containers maintained at $39^{\circ} \mathrm{C}$. Rumen fluid was pooled and inoculated into fermentors at $50 \%$ of fermentor working volume, with the remainder being filled with buffer previously bubbled with $\mathrm{O}_{2}$-free $\mathrm{CO}_{2}$ and maintained at $39^{\circ} \mathrm{C}$. Clarified rumen fluid (centrifuged at $15,000 \times$ $g, 4^{\circ} \mathrm{C}, 15 \mathrm{~min}$, and autoclaved) was used in a 1:20 dilution of buffer for the first day of each period (Wenner et al., 2017).

The liquid (buffer) infusion was maintained at a constant $10.0 \% / \mathrm{h}$. Buffer was made according to Weller and Pilgrim (1974), with the addition of $0.1 \mathrm{~g} / \mathrm{L}$ of urea predicted to maintain $\mathrm{NH}_{3}-\mathrm{N}$ concentration in the fermentor above $5 \mathrm{mg} / \mathrm{dL}$. Adding $\mathrm{H}_{3} \mathrm{PO}_{4}$ or $\mathrm{NaOH}$ as necessary to that buffer, the low $\mathrm{pH}$ buffer was maintained between 6.3 and 6.4 , but high $\mathrm{pH}$ buffer was maintained between 6.7 and 6.8 before infusion into the fermentors. Buffer was continuously bubbled with $\mathrm{O}_{2}$ free $\mathrm{CO}_{2}$ for $1 \mathrm{~d}$ before use and while being infused into the fermentors. Before each period, the fermentor seals were tested with a manual pressure pump (Wenner et al., 2020), and any leaks were repaired.

Fermentors were fed $50 \mathrm{~g}$ (as-fed basis) of a 50:50 concentrate:forage diet twice daily $(93.5 \mathrm{~g} / \mathrm{d}$ of DM; 0800 and $2000 \mathrm{~h}$ ) as a single meal through a port that was opened only at feeding. The diet consisted of a mixture of $17 \%$ alfalfa hay pellets, $33 \%$ orchard grass hay pellets, and $50 \%$ concentrate pellet. Concentrate pellet was composed of $68.0 \%$ corn grain, $6.4 \%$ soybean hulls, $2.0 \%$ corn oil, $20.0 \%$ soybean meal $(48 \%$ CP), $0.40 \%$ dicalcium phosphate, $1.0 \%$ trace mineral supplement, $0.8 \%$ limestone, $0.2 \%$ magnesium oxide, and $0.3 \%$ Se supplement $\left(200 \mathrm{mg} / \mathrm{kg}\right.$ supplied as $\mathrm{Na}_{2} \mathrm{SeO}_{3}$ ). On a dry matter basis, the mixed diet had $23.7 \%$ starch, $15.4 \% \mathrm{CP}$, and $32.6 \%$ NDF (measured by wet chemistry methods at Cumberland Valley Analytical Services, Waynesboro, PA). Dosing of BCVFA started on d 2 (1 mmol of each of the 3 BCVFA at each of 2 daily feedings), allowing for $7 \mathrm{~d}$ of adaptation to the treatment before sampling. A priming dose of $50 \mathrm{mg}$ of $10 \%$ ${ }^{15} \mathrm{~N}$-enriched $\left(\mathrm{NH}_{4}\right)_{2} \mathrm{SO}_{4}$ (Isotec Stable Isotopes) was bolus-dosed into each fermentor on $\mathrm{d} 5$ and added to the buffer at $22.5 \mathrm{mg} / \mathrm{L}$ for a desired enrichment of 0.2 atom percentage excess. Agitation was set to $50 \mathrm{rpm}$ to ensure thorough mixing of substrate in the fermentor, and temperature was kept at $39^{\circ} \mathrm{C}$. The protozoa were primarily effluxed through a filter with a $300-\mu \mathrm{m}$ pore size; their counts inside each fermentor were assessed at d 1,3,5, and 7 after inoculation and were below detection by $\mathrm{d} 7$ (data not shown).

\section{Sample Collection, Processing, and Analyses}

Daily Samples. Daily effluent from the fermentors was collected twice a day over $12 \mathrm{~h}$ after feeding in outflow containers on ice. Liquid and solid effluent were weighed separately. A $15 \%$ (by weight) subsample of 12-h effluent was aspirated with a 6.35 - $\mathrm{mm}$ diameter tube while stirring to prevent sampling bias against larger particles. Effluent subsamples were stored at $-20^{\circ} \mathrm{C}$ until the end of the period, after which liquid and solids were reconstituted per collection, which were subsequently pooled by fermentor within period and dried at $55^{\circ} \mathrm{C}$. A subsample of effluent was dried at $105^{\circ} \mathrm{C}$ overnight to determine $\mathrm{DM}$, then ashed at $550^{\circ} \mathrm{C}$ overnight to determine OM (AOAC, 1990). Residual NDF in the subsample was determined by reflux units with use of heat-stable amylase (Ankom Technology, 2017) and sodium sulfite (Van Soest et al., 1991). Dried effluent nitrogen was determined by the Kjeldahl method (AOAC, 1990). About $1 \mathrm{~g}$ of effluent sample was dissolved in $10 \mathrm{~mL}$ of distilled $\mathrm{H}_{2} \mathrm{O} ; \mathrm{NH}_{3}-\mathrm{N}$ was analyzed (Chaney and Marbach, 1962) and determined to be negligible. Starch in the effluent was sent to be analyzed in a commercial laboratory (Cumberland Valley Analytical Services, Waynesboro, PA).

At the time of effluent collection, a 10-mL sample was obtained using the same aspiration method described previously, mixed with $2 \mathrm{~mL}$ of $25 \%$ metaphosphoric acid, and stored frozen for subsequent VFA analysis. A separate $30-\mathrm{mL}$ sample was frozen immediately and stored at $-80^{\circ} \mathrm{C}$ for subsequent DNA extraction (Roman-Garcia et al., submitted).

Two samples of $250 \mathrm{~mL}$ each were taken from effluent for bacterial pellet collection; the $\mathrm{pH}$ was adjusted to 2.0 (monitored with $\mathrm{pH}$ meter) by adding $5 N \mathrm{HCl}$ dropwise (about $8 \mathrm{~mL}$ ) and then stored at $4^{\circ} \mathrm{C}$ until particle-associated bacteria were harvested as described (Roman-Garcia et al., 2021a). From the supernatant of bacterial pellet collection, samples were collected for $\mathrm{NH}_{3}-\mathrm{N}$ detection by colorimetry (Chaney and Marbach, 1962; Roman-Garcia et al., 2021a) and ammonia diffusion into filter disks (Hristov et al., 2001). The 2 pellets from both 12 -h samples per day 
were combined, resuspended, washed twice with saline, and then divided into 2 replicate pellets per day per fermentor. One of the pellets was used for fatty acid analysis (Roman-Garcia et al., 2021a). The other pellet was analyzed for ${ }^{15} \mathrm{~N}$ and ${ }^{13} \mathrm{C}$ enrichments and $\mathrm{N}$ and $\mathrm{C}$ percentages in an elemental analyzer (Roman-Garcia et al., 2021a) and for OM (AOAC, 1990). Microbial ${ }^{15} \mathrm{~N}$ enrichment was analyzed as described by Noftsger et al. (2003). Background samples were taken before dosing to correct enrichments to atom percentage excess. The VFA sample was processed and analyzed according to Roman-Garcia et al. (2021a) except that, after the valerate peak eluted, the oven temperature was increased to $195^{\circ} \mathrm{C}$ at a rate of $25^{\circ} \mathrm{C}$ per min for another $15 \mathrm{~min}$ until elution of the caproate peak. Pivalic acid was used as an internal standard. Daily production of VFA was calculated by measuring concentration in the effluent times the effluent volume; net production was derived by subtracting the daily dose of BCVFA.

Hourly Gas and Filtrate Sampling. On d 2 to 8 of the adaptation phase, $\mathrm{pH}$ and oxidation reduction potential (ORP) measurements were taken at each hour after the morning feeding. Measurement of $\mathrm{CH}_{4}$ and $\mathrm{H}_{2}$ emission were recorded on 4 of the 8 fermentors on $\mathrm{d}$ 9 to 12 via a Micro-Oxymax Respirometer (Columbus Instruments Inc.) as described by Wenner et al. (2017). Those fermentors were balanced for treatment $(\mathrm{n}=$ 2). Fermentors were opened only for feedings; gas data during that time were discarded. Hydrogen balance was calculated as derived by Ungerfeld et al. (2019).

All hourly samples were obtained in the last $4 \mathrm{~d}$ of the period for all fermentors. Using a $\mathrm{y}$-valve septum inserted into the liquid effluent line, $5 \mathrm{~mL}$ of filtrate was removed from the fermentors at $0,0.5,1,2,4$, 6,8 , and $12 \mathrm{~h}$ after feeding, mixed with $1 \mathrm{~mL}$ of $25 \%$ metaphosphoric acid, and frozen to be processed later for VFA analysis as described previously. To measure aqueous $\mathrm{H}_{2}$ [hereafter referred to as $\mathbf{H}_{2}(\mathbf{a q})$ ], a $20-\mathrm{mL}$ sample was removed using the y-valve septum at 0,1 , $2,4,6,8$, and $12 \mathrm{~h}$ after feeding and injected into a 60-mL glass culture bottle (Wheaton Glass) that was previously dosed with $5 \mathrm{~mL}$ of $5 M_{3} \mathrm{PO}_{4}$ before being flushed with $\mathrm{N}_{2}$ and sealed with a butyl rubber stopper (Wenner et al., 2017).

\section{Statistical Analysis}

Daily VFA production, digestibility, and nitrogen flows were analyzed using PROC MIXED in SAS 9.4 (SAS Institute Inc.) according to this model:

$$
\begin{gathered}
Y_{i j s k l}=\mu+B_{i}+H_{j}+K_{s}+(B \times H)_{i j}+(H \times K)_{j s} \\
+(B \times K)_{i s}+(B \times H \times K)_{i j s}+f_{l}+p_{k}+\varepsilon_{i j s k l},
\end{gathered}
$$

where $Y_{i j s k l}$ is the dependent variable; $\mu$ is the overall population mean; $B_{i}$ is the fixed effect of BCVFA dose ( $i=$ control, BCVFA); $H_{j}$ is the fixed effect of $\mathrm{pH}$ treatment $(j=$ high, low $) ; K_{s}$ is the fixed effect of $\mathrm{k}_{\mathrm{p}}(s=$ high, low $) ;(B \times H)_{i j},(H \times K)_{j s},(B \times K)_{i s}$, and $(B \times H$ $\times K)_{i j s}$ are respective interactions; $f_{l}$ is the fixed effect of fermentor $(l=1-8) ; p_{k}$ is the random effect of $k$ th period ( $k=1-4)$; and $\varepsilon_{i j s k l}$ is the random error. For gas measurement, only 4 fermentors per period $(l=1-4)$ were used ( $\mathrm{n}=2$ rather than 4$)$. Hourly data were analyzed using the REPEATED (repeated measures) statement added to the previous model. The first-order autoregressive (for hourly $\mathrm{CH}_{4}$ and $\mathrm{H}_{2}$ emission), the heterogeneous first order autoregressive (for hourly $\mathrm{pH}$ and ORP), or the spatial power [for unequally spaced hourly VFA and $\mathrm{H}_{2}(\mathrm{aq})$ ] covariate structures were used based on the lowest Bayesian information criterion. When any of the treatments interacted with time $(P \leq$ $0.05)$, the effect of the treatments was contrasted over time, and means per hour were reported. Differences were declared at $P \leq 0.05$, and trends were declared at $0.05<P \leq 0.10$.

\section{RESULTS}

Apparent and true OM degradability were not affected by any of the treatments; nor was an interaction detectable among the treatments (Table 1). Dosing BCVFA tended ( $P=0.09$; main effect) to increase NDF degradability. Contrary to our hypotheses, the low $\mathrm{pH}$ main effect only approached significance $(P=$ 0.11 ) for decreasing NDF degradability compared with high $\mathrm{pH}$. We found no treatment by time interaction, but hour had an effect $(P<0.01)$ on $\mathrm{pH}$, so hourly means are presented in Figure 1A. Lines were parallel between high and low $\mathrm{pH}$ treatments, reached a $\mathrm{pH}$ nadir at about $4 \mathrm{~h}$ after feeding, and then increased until the next feeding.

No treatment by time interaction occurred for ORP (Table 1$)$, which was affected $(P<0.05)$ by time $($ Figure 1B). Curves were generally similar compared with high and low $\mathrm{pH}$ treatments, with higher $\mathrm{pH}$ inherently related to lower ORP measures (Stumm and James, 1970). Lowest (most negative) ORP were recorded about $1 \mathrm{~h}$ after feeding. Then, ORP increased up to $7 \mathrm{~h}$ following feeding, after which it decreased until the next feeding. We detected an interaction $(P<0.01)$ between $\mathrm{pH}$ and $\mathrm{k}_{\mathrm{p}}$ treatments such that, when $\mathrm{pH}$ was low, increasing $\mathrm{k}_{\mathrm{p}}$ decreased ORP; however, when $\mathrm{pH}$ was high, increasing $k_{p}$ increased ORP. Hydrogen balance was not affected by any of the treatments (Supplemental Table S1; https://doi.org/10.3168/jds.2021-20335).

Dosing BCVFA increased $(P<0.01$; main effect $)$ daily $\mathrm{CH}_{4}$ emission (Table 1). No interactions between 


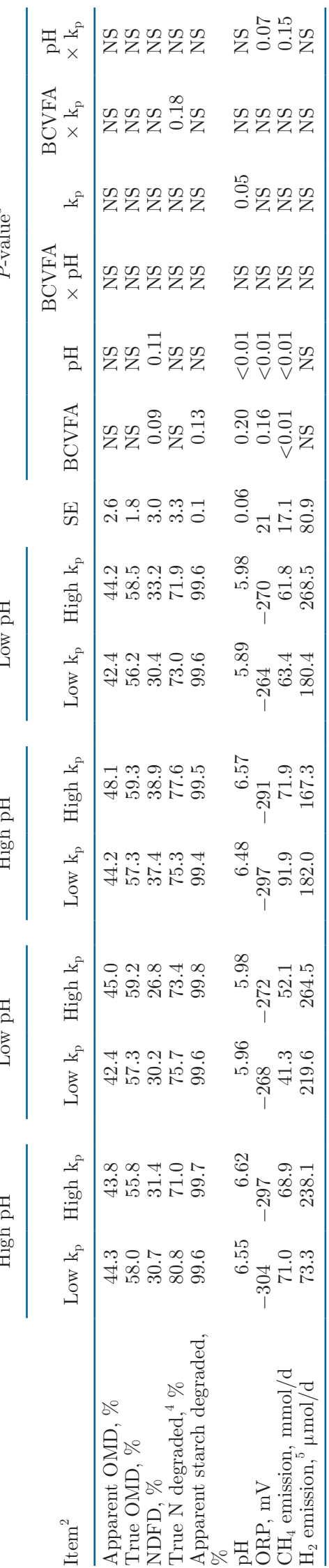$$
\text { กั่ }
$$$$
\wedge
$$$$
\wedge
$$$$
\infty
$$

BCVFA, $\mathrm{k}_{\mathrm{p}}$, or $\mathrm{pH}$ treatments and no main effect of $\mathrm{k}_{\mathrm{p}}$ were detected for $\mathrm{CH}_{4}$ emissions. Decreasing $\mathrm{pH}$ decreased $(P<0.01) \mathrm{CH}_{4}$ emission. We observed similar but opposite patterns for daily $\mathrm{H}_{2}$ emission relative to $\mathrm{CH}_{4}$ emission but no effects $(P>0.15)$ of treatment on daily $\mathrm{H}_{2}$ emissions.

Treatment by time interactions occurred $(P<0.05)$ for $\mathrm{H}_{2}(\mathrm{aq})$ concentration, $\mathrm{CH}_{4}$ hourly emission rate, and $\mathrm{H}_{2}$ hourly emission rate. Hourly $\mathrm{H}_{2}(\mathrm{aq})$ was decreased by low $\mathrm{pH}$ from 2 to $6 \mathrm{~h}$ after feeding and $12 \mathrm{~h}$ after feeding (Figure 2A). Hourly concentration of $\mathrm{H}_{2}(\mathrm{aq})$ was not affected by $\mathrm{k}_{\mathrm{p}}$ or BCVFA. Low $\mathrm{pH}$ decreased $(P<0.05)$ hourly $\mathrm{CH}_{4}$ emission rate from 1 to $4 \mathrm{~h}$ after feeding and tended $(P \leq 0.10)$ to decrease hourly $\mathrm{CH}_{4}$ emission rate up to $6 \mathrm{~h}$ after feeding (Figure 2B). Low $\mathrm{pH}$ increased $(P<0.05) \mathrm{H}_{2}$ emission rates from 0.5 to $1.5 \mathrm{~h}$ and $3 \mathrm{~h}$ after feeding (Figure $2 \mathrm{C}$ ). From 1 to $2 \mathrm{~h}$ following feeding, high $\mathrm{k}_{\mathrm{p}}$ increased $\mathrm{H}_{2}$ emission rate. An interaction occurred between $\mathrm{k}_{\mathrm{p}}$ and $\mathrm{pH}$ for 5 to 9 $\mathrm{h}$ after feeding such that high $\mathrm{k}_{\mathrm{p}}$ increased $\mathrm{H}_{2}$ emission rates only in the low $\mathrm{pH}$ treatment.

Total $\mathrm{N}$ flows were not affected $(P>0.10)$ by treatment or interactions among treatments (Table 2). Bacterial $\mathrm{N}$ derived from $\mathrm{NH}_{3}$ tended to increase $(P=$ 0.09) with the main effect of high $k_{p}$ relative to low $k_{p}$ but was not affected by any other treatment. Bacterial $\mathrm{N}$ flow, NAB flow, nonammonia nonbacterial $\mathrm{N}$ flow, and bacterial $\mathrm{N}$ flow per unit of true $\mathrm{OM}$ or unit of carbohydrate degraded were not affected $(P>0.10)$ by any treatment. Increasing $\mathrm{k}_{\mathrm{p}}$ increased nonammonia nonbacterial $\mathrm{N}$ flow as a percentage of NAN flow when BCVFA were not dosed (BCVFA $\times \mathrm{k}_{\mathrm{p}}$ interaction, $P$ $=0.09$ ).

Daily net production (subtraction of BCVFA dosage from BCVFA gross production) of total VFA was not affected by BCVFA dosing, $\mathrm{pH}$, or any interactions (Table 3). However, the main effect of high $\mathrm{k}_{\mathrm{p}}$ tended to decrease $(P=0.09)$ net production of total VFA and decreased $(P=0.05)$ production of acetate. Low $\mathrm{pH}$ decreased $(P<0.01)$ acetate and increased $(P<$ $0.01)$ propionate production; thus, decreasing $\mathrm{pH}$ also decreased $(P<0.01)$ the ratio of acetate to propionate. Butyrate and caproate productions were not affected by any treatment. Low $\mathrm{pH}$ decreased $(P<0.05)$ net production of isobutyrate and isovalerate but increased $(P<0.01)$ 2-methylbutyrate net production compared with high $\mathrm{pH}$. Valerate recovery also increased $(P=$ 0.04) with low $\mathrm{pH}$.

Hour interacted with treatment $(P<0.05)$ for molar percentages of isovalerate, isobutyrate, and 2-methylbutyrate in fermentor contents. Isovalerate (Figure 3A), isobutyrate (Figure 3B), and 2-methylbutyrate (Figure $3 \mathrm{C})$ molar percentages increased $(P<0.01)$ by dosing BCVFA, as planned, because these values 
(A)

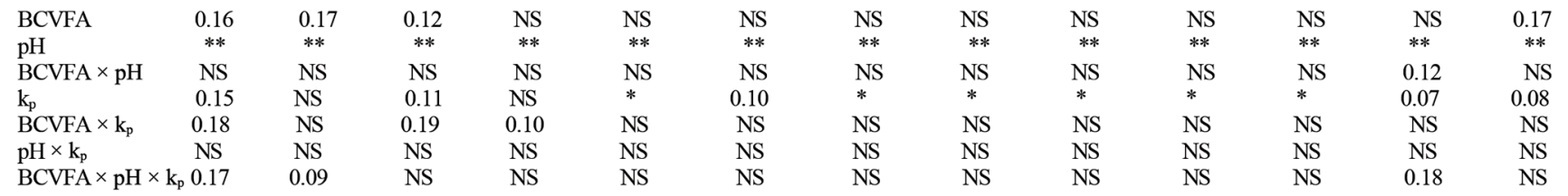

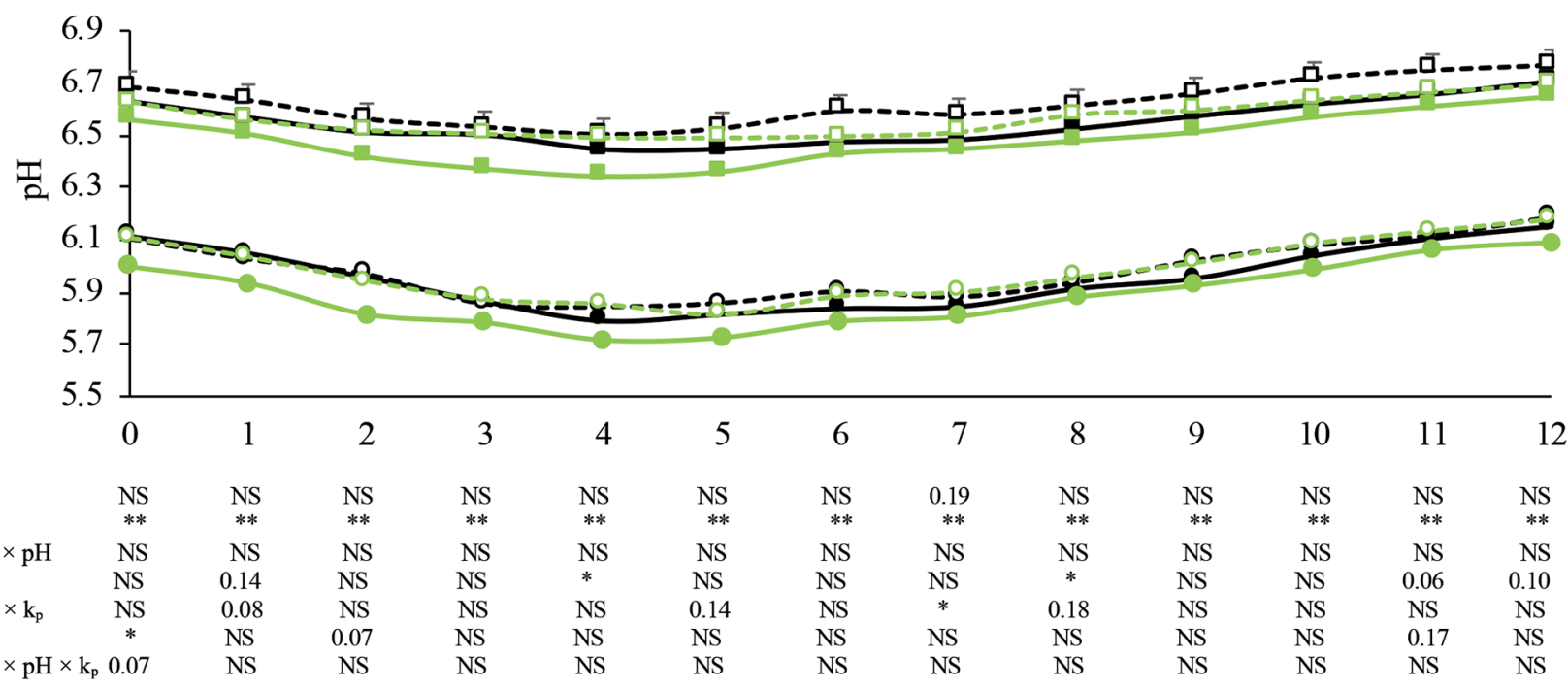





\footnotetext{
$\rightarrow$ Control- High pH- Low $\mathrm{k}_{\mathrm{p}} \quad-\square--$ Control- High pH- High $\mathrm{k}_{\mathrm{p}} \rightarrow-$ Control- Low pH- Low $\mathrm{k}_{\mathrm{p}} \quad-\circ-$ Control- Low pH- High $\mathrm{k}_{\mathrm{p}}$

- - BCVFA- High pH- Low $\mathrm{k}_{\mathrm{p}}--\square--$ BCVFA-High pH- High $\mathrm{k}_{\mathrm{p}} \longrightarrow-$ BCVFA- Low pH- Low $\mathrm{k}_{\mathrm{p}}--\circ--$ BCVFA- Low pH- High $\mathrm{k}_{\mathrm{p}}$
}

Figure 1. Fermentor $\mathrm{pH}(\mathrm{A})$ and redox (B) over time after feeding for continuous cultures that had treatments of either high or low $\mathrm{pH}$ and either low or high solids passage rate $\left(\mathrm{k}_{\mathrm{p}}\right)$. Data are means from all 4 experimental periods taken on $\mathrm{d} 1$ to 7 of the period. Buffers were adjusted to control pH. Because the branched-chain VFA (BCVFA) treatment was given in the form of acid, it lowered pH by approximately 0.06 unit. Hour did not interact with any of the treatments. The main effects and interactions of treatments were tested at each time point and are reported as follows: ${ }^{* *} P \leq 0.01 ;{ }^{*} P \leq 0.05 ;{ }^{\mathrm{NS}} P>0.20$. The SEM is pooled across treatment per time and shown for only 1 series per plot.

are not corrected for dosage of BCVFA; this increase lasted from 0.5 to $12 \mathrm{~h}$ after feeding. With lower $\mathrm{pH}$, the molar percentages of isovalerate and isobutyrate were lower $(P<0.01)$ at all hours, whereas 2 -methylbutyrate had the opposite pattern of higher molar percentages on the low versus high $\mathrm{pH}$ treatment.
For 2-methylbutyrate, a tendency $(P=0.08)$ for an interaction between BCVFA and $\mathrm{pH}$ was detected at $8 \mathrm{~h}$ after feeding. When BCVFA were not dosed, low $\mathrm{pH}$ had consistent patterns over the $12 \mathrm{~h}$. In contrast, when BCVFA were dosed, the 2-methylbutyrate molar percentage on the low $\mathrm{pH}$ treatment remained high, 


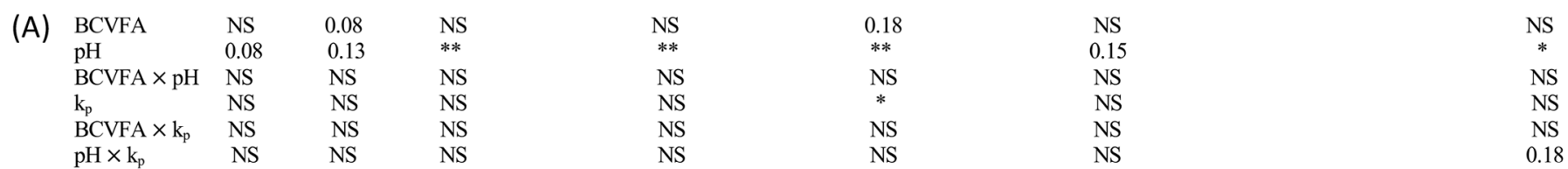

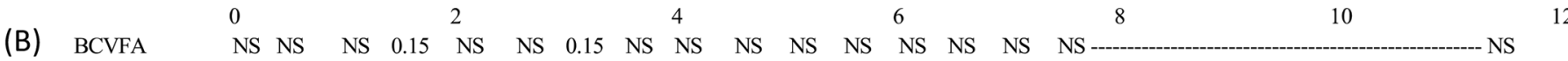
$\begin{array}{lllllllllllllllllllllllllllllll}\mathrm{pH} & 0.20 & 0.07 & * & * * & * * & * * & * * & * & * & 0.06 & 0.08 & 0.13 & 0.10 & 0.15 & 0.13 & 0.17 & \text { NS } & \text { NS } & \text { NS } & \text { NS NS NS NS NS }\end{array}$ BCVFA $\times$ pH $\quad$ NS $\mathrm{k}_{\mathrm{p}} \mathrm{NS}-\mathrm{n}$ BCVFA $\times k_{p} \quad$ NS NS NS $0.16 \quad$ NS $\begin{array}{llllllllllllllllllllllllll}\mathrm{pH} \times \mathrm{k}_{\mathrm{p}} & 0.15 & \mathrm{NS} & \mathrm{NS} & 0.19 & \mathrm{NS} & \mathrm{NS} & \mathrm{NS} & \mathrm{NS} & \mathrm{NS} & \mathrm{NS} & \mathrm{NS} & 0.12 & 0.18 & \text { NS } & \text { NS } & \text { NS } & 0.15 & 0.12 & \text { NS } & \text { NS } & \text { NS } & \text { NS } & \text { NS } & \text { NS }\end{array}$

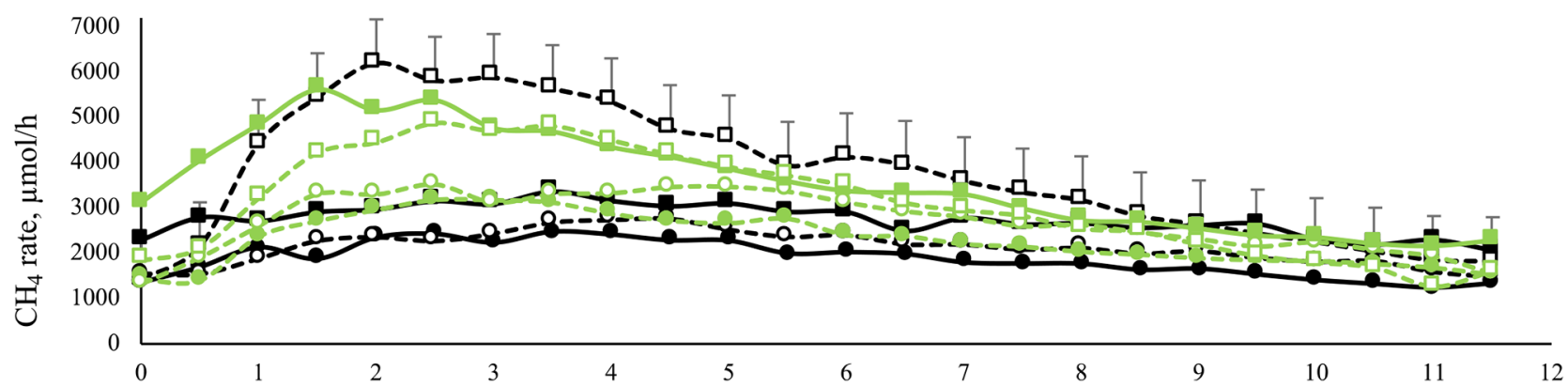

$\begin{array}{lllllllllllllllllllllllllllll}\text { (C) } & \text { BCVFA } & \text { NS } & \text { NS } & 0.13 & \text { NS } & \text { NS } & \text { NS } & \text { NS } & \text { NS } & \text { NS } & \text { NS } & 0.15 & * & \text { NS } & \text { NS } & * & 0.18 & \text { NS } & 0.19 & 0.17 & \text { NS } & 0.14 & \text { NS } & 0.19 & 0.08\end{array}$

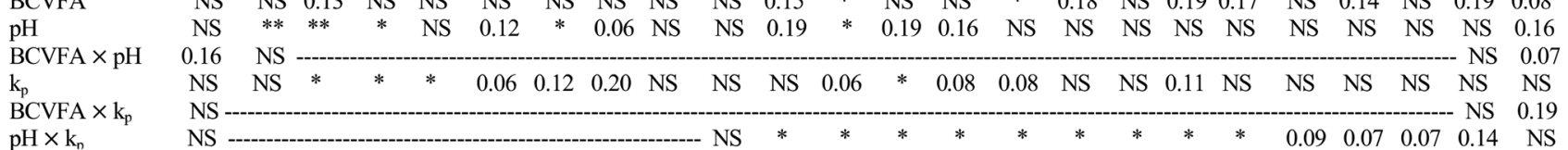

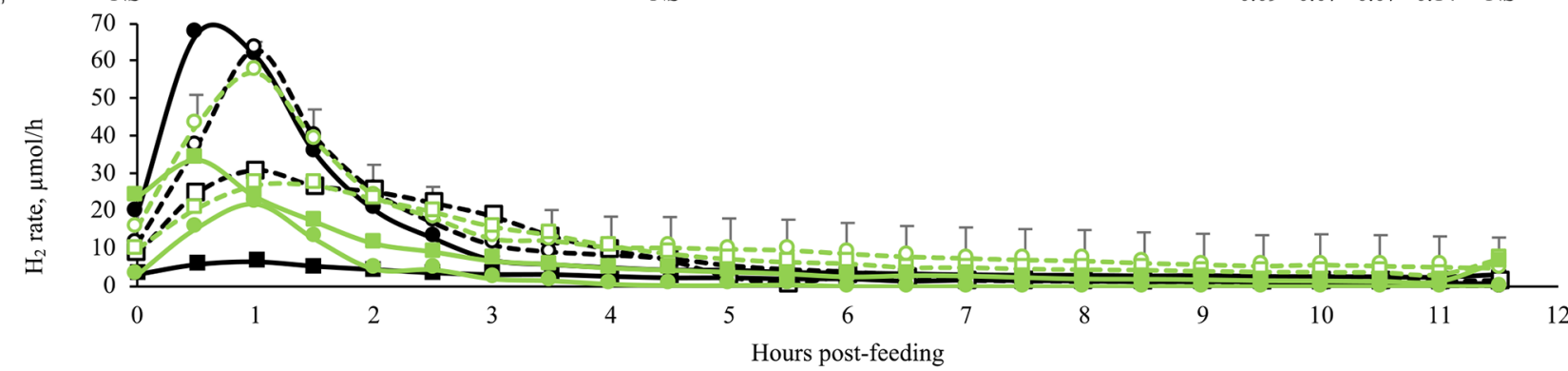

$\rightarrow-$ Control- High pH- Low $k_{p} \quad--\square-\cdot$ Control- High pH- High $k_{p} \rightarrow-$ Control- Low pH- Low $k_{p} \quad--0--$ Control- Low pH- High $k_{p}$ - - BCVFA- High pH- Low $\mathrm{k}_{\mathrm{p}}-\square--$ BCVFA-High pH- High $\mathrm{k}_{\mathrm{p}} \longrightarrow$ - BCVFA- Low pH- Low $\mathrm{k}_{\mathrm{p}} \quad--\mathrm{-}-\mathrm{BCVFA-} \mathrm{Low} \mathrm{pH-} \mathrm{High} \mathrm{k}_{\mathrm{p}}$

Figure 2. Aqueous $\mathrm{H}_{2}$ concentration (A), and emission rates of $\mathrm{CH}_{4}(\mathrm{~B})$ and $\mathrm{H}_{2}(\mathrm{C})$ over time after feeding in continuous cultures that were dosed without or with branched-chain VFA (BCVFA) and maintained at either high or low $\mathrm{pH}$ and either low or high solids passage rate ( $\mathrm{k}_{\mathrm{p}}$ ). Treatment by time interaction was detected for all of these variables. The main effects and interactions of treatments were tested at each time point and are reported as follows: ${ }^{* *} P \leq 0.01 ;{ }^{*} P \leq 0.05 ;{ }^{\mathrm{NS}} P>0.20$. Dashed line indicates NS for the entire span of time points; BCVFA $\times$ pH $\times \mathrm{k}_{\mathrm{p}}$ was not significant at any time point for any variable. The SEM is pooled across treatment per time and shown for only 1 series per plot. 


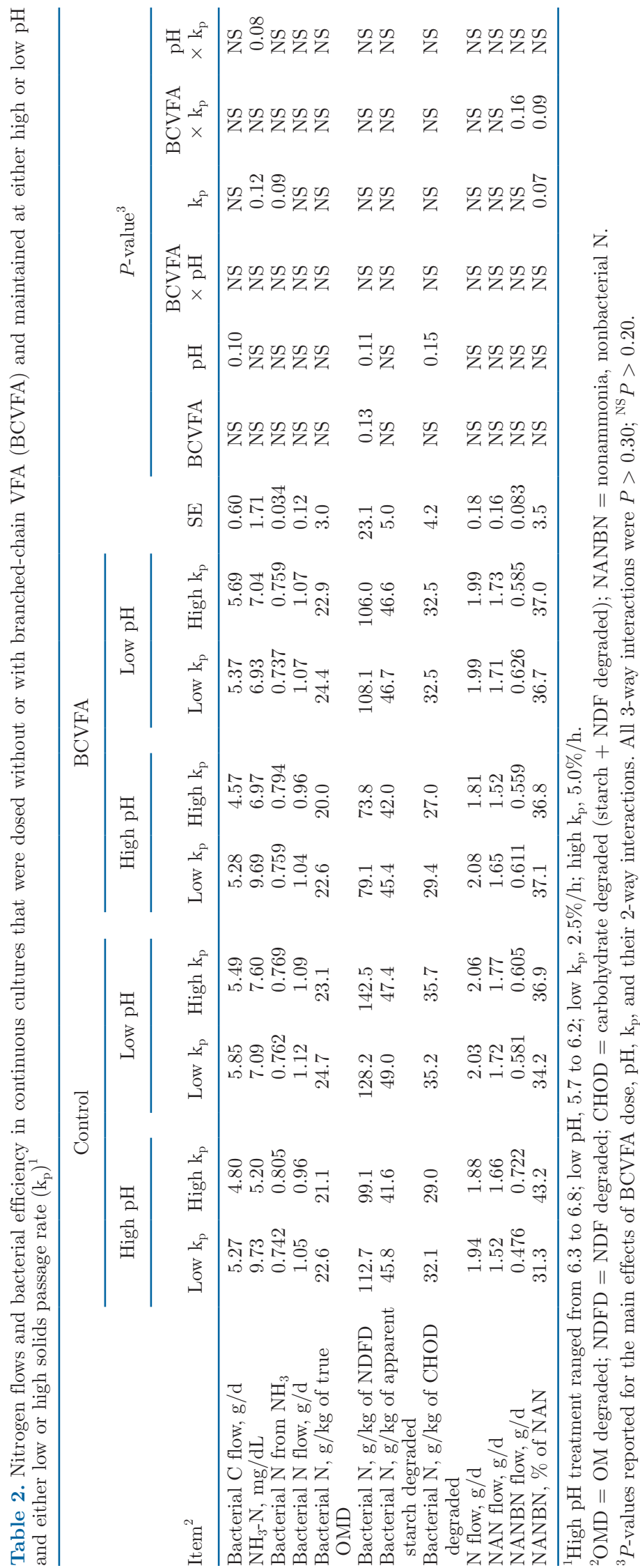




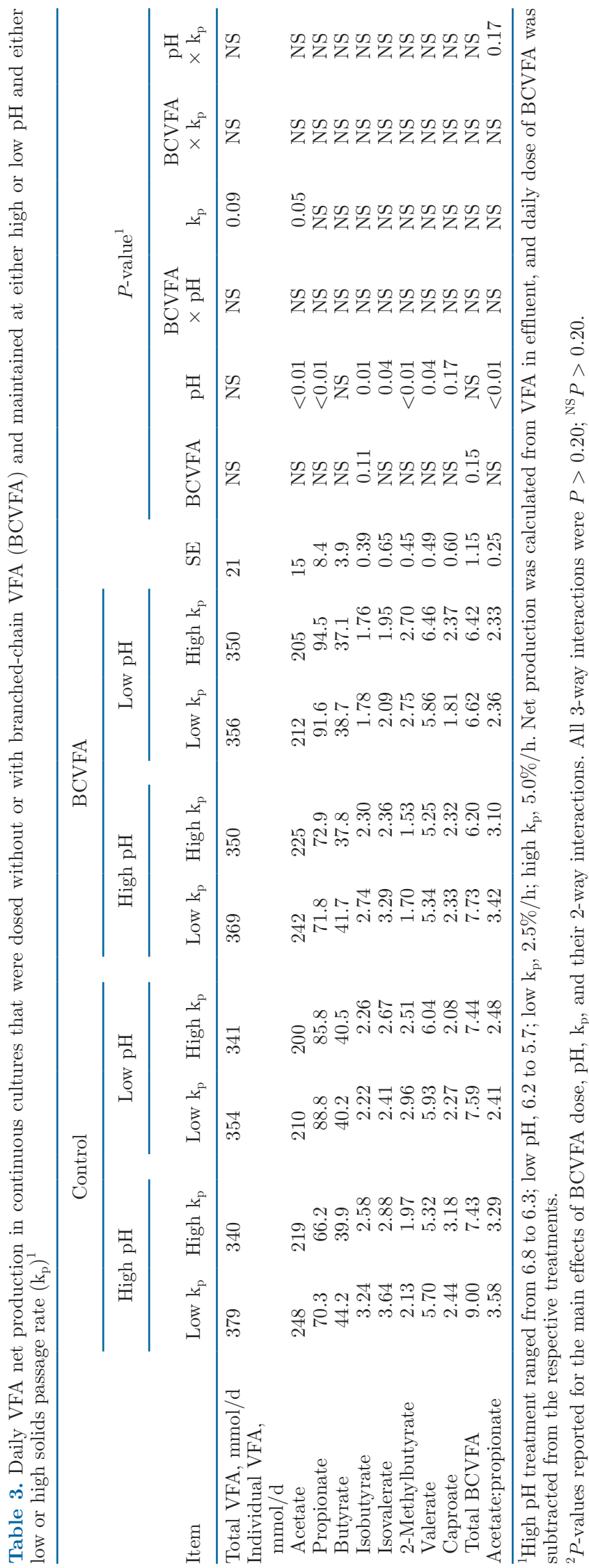

whereas high $\mathrm{pH}$ decreased 2-methylbutyrate down to control BCVFA treatments by $8 \mathrm{~h}$. Tabular main effect means are shown in Supplemental Table S2 (https:// doi.org/10.3168/jds.2021-20335).

\section{DISCUSSION}

\section{Nutrient Degradability and Methane Production}

Dosing BCVFA tended to increase NDF degradability by 5.2 percentage units, probably due to cellulolytic bacterial requirements for BCVFA (Stewart et al., 1997). Results are consistent with results from mixed ruminal microbes degrading grass hay plus corn in batch culture (Roman-Garcia et al., 2021a). Low $\mathrm{pH}$ only approached $(P=0.11)$ a decrease in NDF degradability. Lack of difference is consistent with results of Wenner et al. (2017). Medium pH is the major determining factor in culture adaptation (Broudiscou et al., 2014). However, our cultures varied $\mathrm{pH}$ over the feeding cycle. The low $\mathrm{pH}$ treatment's initial $\mathrm{pH}$ being about 6.0 (Figure 1A) might have been high enough to minimize the effects of low $\mathrm{pH}$ on fiber degradation (Mouriño et al., 2001). Some of the negative effects of starch on NDF degradability are independent of $\mathrm{pH}$. Low pH-tolerant amylolytic bacteria can outcompete for growth factors such as BCVFA to reduce NDF degradability in mixed forage and grain diets (Firkins, 2010). Even so, we detected no interactions of $\mathrm{pH}$ with BCVFA on NDF degradability.

Intimate contact of extracellular carbohydratedegrading complexes to substrates is critical for fiber degradation (Terry et al., 2019). Based on an increased membrane fluidity when switching from cellobiose to cellulose as substrate (Moon and Anderson, 2001), we hypothesize that membrane fluidity is essential for translocation of these enzymes and supporting proteins extracellularly. A dynamic interchange of BCVFA between amylolytics and cellulolytics is critical for optimal fiber degradation (Moraïs and Mizrahi, 2019). Consequently, a higher local concentration of BCVFA by supplementing BCVFA might help cellulolytics acquire these precursors either for reductive carboxylation to BCAA or as primers for bacterial branched-chain fatty acids needed to maintain membrane fluidity required for adhesion and subsequent colonization (RomanGarcia et al., submitted).

Measurements of ORP in aqueous solutions represent the tendency to gain (be reduced) or lose (be oxidized) electrons. The more negative the ORP, the more reduced the solution is. Because most redox reactions are coupled with protons, $\mathrm{pH}$ and ORP are negatively correlated (Krishtalik, 2003). Although relatively few studies have reported ORP, Huang et al. (2018) noted 


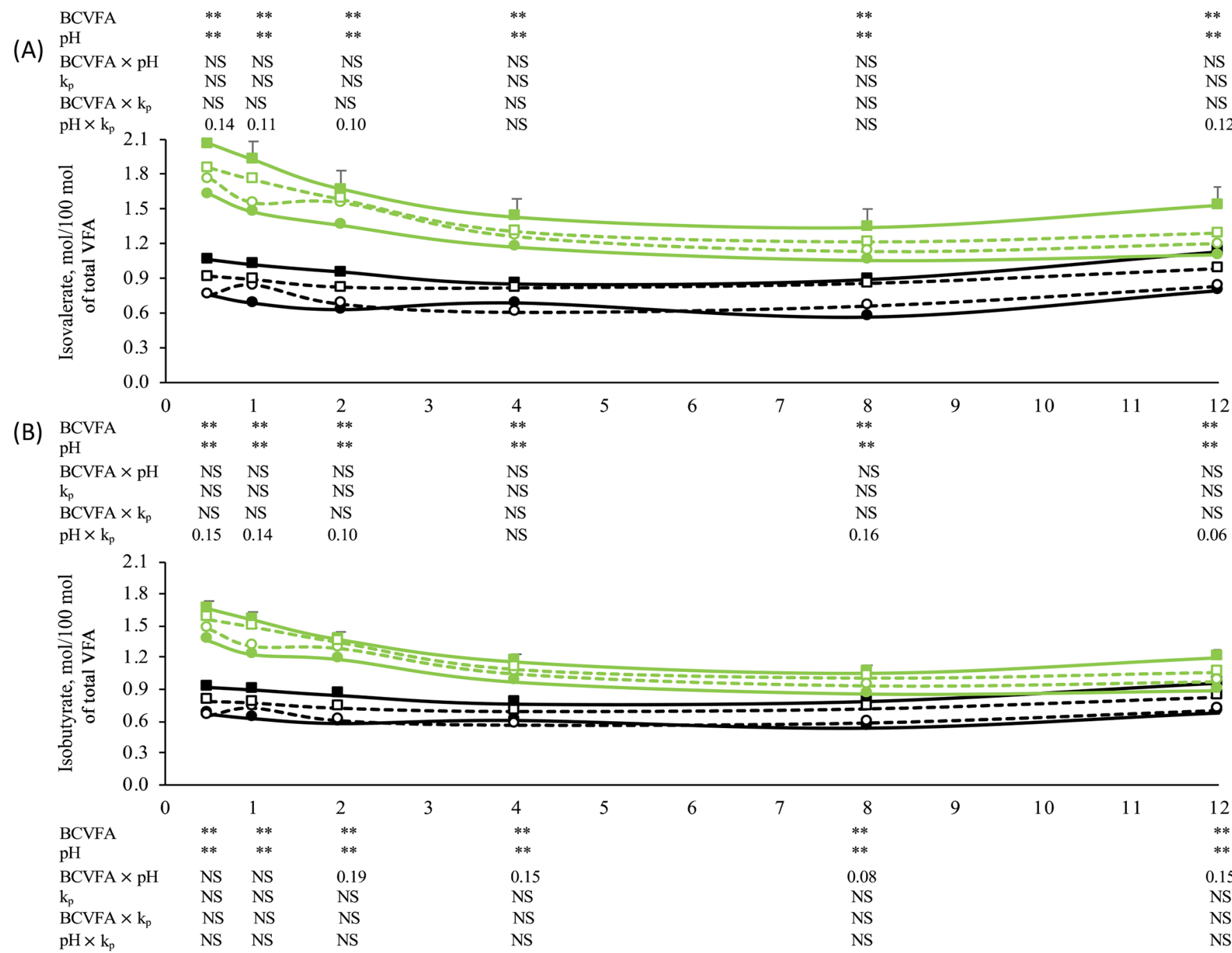

(C)

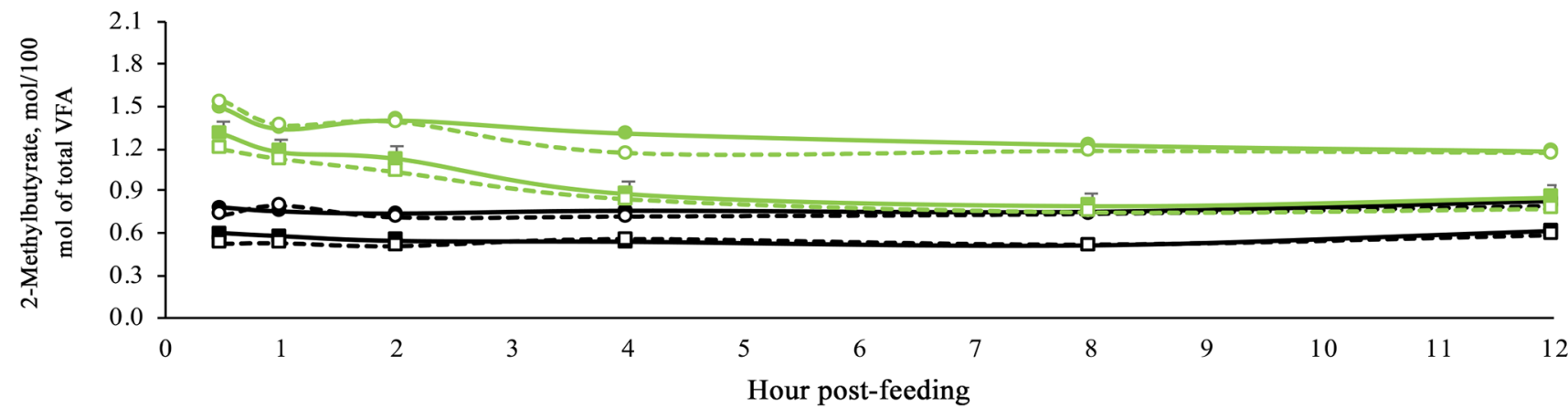

\footnotetext{
$\rightarrow-$ Control- High pH- Low $k_{p} \quad-\square--$ Control- High pH- High $k_{p} \rightarrow-$ Control- Low pH- Low $k_{p} \quad--0--$ Control- Low pH- High $k_{p}$ - - BCVFA- High pH- Low $\mathrm{k}_{\mathrm{p}}--\square--$ BCVFA-High pH- High $\mathrm{k}_{\mathrm{p}} \longrightarrow-$ BCVFA- Low pH- Low $\mathrm{k}_{\mathrm{p}}--\circ--$ BCVFA- Low pH- High $\mathrm{k}_{\mathrm{p}}$
}

Figure 3. Molar percentage of the individual branched-chain VFA (BCVFA) isovalerate (A), isobutyrate (B), and 2-methylbutyrate (C) over time after feeding in continuous cultures that were dosed without or with BCVFA and maintained at either high or low $\mathrm{pH}$ and either low or high solids passage rate $\left(k_{\mathrm{p}}\right)$. These data are not corrected for BCVFA dose. Treatment by time interaction was detected for all of these variables. The main effects and interactions of treatments were tested at each time point and are reported as follows: $* * P \leq 0.01 ;{ }^{*} P \leq 0.05$; ${ }^{\mathrm{NS}} P>0.20$. Three-way interactions were all not significant. The SEM is pooled across treatment per time and shown for only 1 series per plot. 
that increasing dietary forage NDF and NDF degradability in vivo were associated with decreasing ORP. However, they did not account for the likely collinearity between forage inclusion with $\mathrm{pH}$; that is, both increasing forage and increasing $\mathrm{pH}$ should decrease ORP. In our study, BCVFA increased NDF degradability (Table 1). Also, $\mathrm{H}_{2}(\mathrm{aq})$, a reductant, increased with high $\mathrm{pH}$ (Figure 2). Similarly, Huang et al. (2018) related increases in acetate production (many pathways of which release $\mathrm{H}_{2}$ ) with lower ORP, which was observed in the high $\mathrm{pH}$ treatment.

Changing particulate $\mathrm{k}_{\mathrm{p}}$ did not affect $\mathrm{CH}_{4}$ emissions in our study, which is contrary to results of Wenner et al. (2017). That study retained protozoa and had a smaller filter compared with our study. The low $\mathrm{pH}$ treatment decreased $\mathrm{CH}_{4}$ emission in our study, which was expected (Van Kessel and Russell, 1996); thus, its precursor, $\mathrm{H}_{2}(\mathrm{aq})$ accumulated early after feeding. Assessment of $\mathrm{H}$ balance did not reveal any treatment differences. Hence, our low $\mathrm{pH}$ treatment might not have extended long enough postprandially to shift the rate of $\mathrm{H}_{2}$ emission long enough over the entire day to suppress daily $\mathrm{H}_{2}$ emission.

Deamination or decarboxylation of BCAA to BCVFA reduces cofactors, which are typically referred to as reducing equivalents and abbreviated as $[2 \mathrm{H}]$. Because inhibition of methanogenesis disrupts deamination of BCAA (Hino and Russell, 1985), we expected that reductive carboxylation (BCVFA converted to BCAA) would consume $[2 \mathrm{H}]$ and compete with methanogenesis. More recently, a role for $[2 \mathrm{H}]$ in AA metabolism and recovered in microbial protein and lipid sinks was discussed, but its role still is not clear (Ungerfeld, 2015; Martinez-Fernandez et al., 2016). In our companion report (Roman-Garcia et al., 2021b), BCVFA tended to increase FA as a percentage of OM in bacterial cells. Methanogens also require BCVFA as a growth factor (Stewart et al., 1997). The relative $16 \mathrm{~S}$ rRNA gene sequence abundance of archaea did not increase with BCVFA treatment (Roman-Garcia et al., 2021b), but we did not measure total $16 \mathrm{~S}$ rRNA gene abundance. Even so, abundance of methanogens is not necessarily indicative of methanogenesis (Firkins et al., 2015). Thus, the most likely reason for increased methanogenesis after dosing BCVFA is a result of increased NDF degradation increasing the $[2 \mathrm{H}]$ pool from a shift toward pathways that liberate more $\mathrm{H}_{2}$ or formate per unit of acetate produced (Janssen, 2010). Increased relative abundance of Fibrobacter (Roman-Garcia et al., 2021b) would not initially support this hypothesis because they do not produce $\mathrm{H}_{2}$, but they do increase crossfeeding by $\mathrm{H}_{2}$-producing bacteria (Martínez-Álvaro et al., 2020). However, inferences are limited because only half of our fermentors measured gas emission (i.e., $\mathrm{n}=$ 2 per treatment).

We expected that lower $\mathrm{pH}$ and thus lower methane production would increase concentration of $\mathrm{H}_{2}(\mathrm{aq})$, but we actually observed a decrease from 2 to $6 \mathrm{~h}$ after feeding. However, we also found higher $\mathrm{H}_{2}$ emission with lower $\mathrm{pH}$ in the early hours following feeding. Increased $\mathrm{H}_{2}$ escape into the headspace can explain the lower concentration in the aqueous phase with low $\mathrm{pH}$. A similar decrease in $\mathrm{H}_{2}(\mathrm{aq})$ concentrations with decreasing $\mathrm{pH}$ was observed by Wenner et al. (2017), who suggested that production of reduced VFA was a sink for the extra $[2 \mathrm{H}]$ in low $\mathrm{pH}$ treatments. Those authors reported higher isovalerate molar proportion with decreasing $\mathrm{pH}$, which was likely a result of coeluted 2-methylbutyrate, which increased in our study and will be further explained in our companion study (Roman-Garcia et al., 2021b). Because methanogenesis is an important sink for $\mathrm{H}_{2}(\mathrm{aq})$, the high $\mathrm{pH}$ treatment was expected to lower $\mathrm{H}_{2}$ emission rates, but this decrease was not consistent at all hours in our study.

\section{Bacterial Protein Synthesis}

The lack of response in protein degradability, bacterial nitrogen flows, and gas emissions to $k_{p}$ treatment contrasted with results from other studies (Qiu et al., 2004; Wenner et al., 2017), probably because our $k_{p}$ treatments did not alter the passage of all the solids (i.e., ground corn) as much as we intended. Supported by our very high observed starch degradability, the grain particles apparently settled below the overflow port and did not pass more quickly into the effluent with increasing $k_{\mathrm{p}}$. The trends for lower total VFA and acetate production with increasing $\mathrm{k}_{\mathrm{p}}$ and decreasing $\mathrm{pH}$ (Table 3) suggests diversion of degraded carbohydrate into cellular matter. Bacterial nitrogen flow was not affected, but bacterial carbon flow tended to increase with decreasing $\mathrm{pH}$ (Table 2). Because the increased carbon was not from FA (Roman-Garcia et al., 2021b), increased glycogen is the most likely explanation. Although glycogen storage is lower in bacteria than protozoa (Hackmann and Firkins, 2015b), glycogen can increase considerably when growth rate is slowed, as by decreasing $\mathrm{k}_{\mathrm{p}}$, as shown for Prevotella ruminicola (Lou et al., 1997). Because starch granules likely were completely degraded, available starch would be very high, and the $k_{p}$ for bacteria associated with starch was effectively very slow; moreover, relative abundance of Prevotella almost doubled with decreasing pH (Roman-Garcia et al., 2021b).

Although BCVFA did not improve microbial nitrogen production or efficiency of microbial protein syn- 
thesis in our study, Russell and Sniffen (1984) noted improved protein synthesis in batch cultures of mixed rumen microbes after adding BCVFA. Similarly, total bacteria and targeted cellulolytic bacteria (using real-time PCR) increased linearly with the addition of isovalerate (Liu et al., 2014), isobutyrate (Wang et al., 2015), or 2-methylbutyrate (Zhang et al., 2015) in steers. By contrast, Cummins and Papas (1985) detected no increase in microbial nitrogen accumulating after incubation with BCVFA in batch cultures when cottonseed meal was the main substrate at $16 \% \mathrm{CP}$ and when corn gluten mean was the substrate at $13 \% \mathrm{CP}$; they still noted increased degradability of wheat straw (much lower $\mathrm{CP}$ ). Considerable interchange appears to occur between BCVFA and BCAA in mixed ruminal microbes (Atasoglu and Guliye, 2004). Whether or not supplemental BCVFA stimulates efficiency of microbial protein synthesis probably depends on the relative limitation of cytosolic free BCAA concentrations (Firkins et al., 2015) under those specific growth conditions and on possible imbalances of the individual BCAA precursors (Kajikawa et al., 2005). Addition of BCVFA did improve amount and efficiency of microbial protein synthesis in continuous cultures under similar conditions to the current study (Mitchell et al., 2020). Increasing $\mathrm{k}_{\mathrm{p}}$ should wash out potentially degradable protein and increase nonammonia nonbacterial $\mathrm{N}$ flow in effluent, but we have no explanation for why this result was noted only in treatments without BCVFA (interaction of BCVFA with $\mathrm{k}_{\mathrm{p}}$ ). The BCAA influence pleiotropic control over genes involved in AA synthesis in bacteria (Kaiser and Heinrichs, 2018). Transcriptional regulation of proteolytic enzymes is not well characterized in ruminal bacteria.

\section{VFA Production}

We expected a decrease in acetate net production with low $\mathrm{pH}$ as a result of acetate being a primary end product of fibrolytic (particularly cellulolytic) bacteria that would be inhibited by low $\mathrm{pH}$ (Stewart et al., 1997). At the same time, low $\mathrm{pH}$ decreased methanogenesis, which can result in intracellular $[2 \mathrm{H}]$ buildup and increased production of propionate or else condensation of acetyl-CoA with exogenous VFA to produce butyrate, valerate, or caproate while decreasing $\mathrm{H}_{2}$-producing acetyl-CoA fermentation pathways (Janssen, 2010). High $\mathrm{k}_{\mathrm{p}}$ also decreased acetate net production compared with low $\mathrm{k}_{\mathrm{p}}$ in our study, which has been noted previously (Janssen, 2010). Increased propionate production in the low $\mathrm{pH}$ treatment (Table 3 ) is likely due to a greater tolerance toward low $\mathrm{pH}$ by amylolytics (Stewart et al., 1997).
We expected addition of BCVFA to decrease net production of individual BCVFA in our study because dosing isobutyrate decreased net production of itself but increased net production of isovalerate in batch cultures (Roman-Garcia et al., 2021a). Other such interactions were noted therein. However, dosing BCVFA in this study only approached significance $(P \leq 0.15)$ to decrease net production of isobutyrate and total BCVFA by 16.7 and $14.4 \%$, respectively. Increased actual (i.e., not net) concentration could increase feedback inhibition of deamination or decarboxylation, increase competition of these BCVFA for primers in FA synthesis, or increase catabolism of BCVFA all while balancing $[2 \mathrm{H}]$. Both BCAA deamination and BCVFA concentrations have had mixed associations with inhibition of methanogenesis that are not yet explained (MartinezFernandez et al., 2016; Ungerfeld, 2018; Wenner et al., 2020). Isovaleryl-CoA was inferred as the main feedback inhibitor in Leu synthesis by $P$. ruminicola (Allison et al., 1984). Hino and Russell (1985) noted that BCAA were metabolized by Stickland reactions but also by mechanisms that those authors did not explain and that remain unexplained for ruminal bacteria. The branched-chain keto acid dehydrogenase in Enterococcus faecalis (phylum Firmicutes) uses $\mathrm{NAD}^{+} / \mathrm{NADH}$ as a cofactor and is a main component of the $b k d$ operon that produces 0.5 ATP per BCAA via substrate-level phosphorylation (Ward et al., 2000). This gene, which is annotated as K00166-7 in Kyoto Encyclopedia of Genes and Genomes orthology (https://www.genome .jp/ $\mathrm{kegg} /$ ), is poorly represented in literature with major ruminal bacteria. However, a similar reaction must be occurring in ruminal bacteria because BCAA deamination and decarboxylation can be critically linked to disposal of $[2 \mathrm{H}]$ via methanogenesis in mixed ruminal microbes (Hino and Russell, 1985). Moreover, BCVFA and BCAA interchange considerably (Atasoglu and Guliye, 2004), which also would require cycling of $[2 \mathrm{H}]$.

Rather than the branched-chain ketoacid dehydrogenase (with $\mathrm{NAD}^{+} / \mathrm{NADH}$ cofactor) described for some model nonrumen bacteria, BCAA and BCVFA interconversion in rumen bacteria has long been reasoned to involve ferredoxin (Allison et al., 1984). Addition of oxidized methylviologen (typically used as a substitute for ferredoxin) to mixed ruminal microbes in batch culture increased BCVFA concentration 9-fold; it generally decreased moles of VFA but increased elongation (using $[2 \mathrm{H}]$ ) to caproate 3 -fold (Nerdahl and Weimer, 2015). Long-chain FA were not measured in their study but also could be elongated as a result of buildup of [2H] (Ungerfeld, 2015). Only oxidized methylviologen (not $\mathrm{NAD}^{+}$or $\mathrm{NADP}^{+}$) greatly increased the activity of branched-chain 2-ketoacid oxidoreductase 
(2-ketoisovalerate oxidoreductase, vor) in 2 Prevotella strains from the human oral community (Takahashi and Yamada, 2000). Those authors explained that these 2 strains are closely related to the ruminal $P$. ruminicola. They also suggested that vor is closely related to or perhaps the same enzyme as pyruvate ferredoxin oxidoreductase (por, a complex well known to use ferredoxin as a cofactor). The vor gene is poorly described, and its activity is likely (but not yet biochemically characterized) to result from evolution of por or 2-ketoacid oxidoreductase (kor) in bacteria (Gibson et al., 2016). Both nifJ (K03737, closely related to por) and kor ABCD (K00174-7) are widespread in the genomes of prevotellas using the Kyoto Encyclopedia of Genes and Genomes orthology database in the Hungate 1000 collection of ruminal prokaryotes (https://img.jgi .doe.gov/). Although apparently not in a $b k d$ operon, an acyl-CoA dehydrogenase (Clusters of Orthologous Groups database, COG1960) is flanked by etfAB genes (electron transfer using ferredoxin or flavodoxin as a cofactor) in the genomes of those prevotellas and likely has activity similar to that of isovaleryl-CoA dehydrogenase, which would be the first step in catabolism of BCVFA-CoA. Unfortunately, annotations are limited, and very few biochemical assays for these reactions are published for ruminal bacteria because of the strictly anaerobic conditions needed, but research is critically needed to explain how bacteria such as the dominant Prevotella group coordinate the anabolic and catabolic pathways intersecting through the BCVFA.

\section{CONCLUSIONS}

Dosing BCVFA increased NDF degradability in continuous cultures but did not increase bacterial protein synthesis. We expected that BCVFA would be highly required with faster bacterial growth (increased efficiency), and we expected to increase this efficiency with faster $k_{p}$. However, the lack of response in NDF degradability, bacterial efficiency, and gas emissions to changes in $k_{p}$ suggest that we did not fully achieve our goal to effectively increase $k_{p}$ of dense feed particles. Contrary to expectations, dosing BCVFA increased methane emission, likely due to increased NDF degradation. As expected, low $\mathrm{pH}$ decreased methane emissions, but the expected increase in $\mathrm{H}_{2}$ emission and $\mathrm{H}_{2}(\mathrm{aq})$ was not apparent in this study, and $[2 \mathrm{H}]$ was most likely redirected to production of reduced VFA such as propionate and valerate. Changes in $\mathrm{pH}$ affected the net production of BCVFA in continuous culture, with resulting mechanisms to be further explored in our companion paper.

\section{ACKNOWLEDGMENTS}

This research was jointly supported by state and federal funds appropriated to the Ohio Agricultural Research and Development Center, The Ohio State University. Research funds were provided by Zinpro Corporation (Eden Prairie, MN). The Summer Research Opportunity Program at The Ohio State University provided funding for 2 years. It is the intent of Zinpro Corporation to eventually commercialize an isoacid product. One of the authors of this paper, M. T. Socha, is an employee of Zinpro Corporation. The authors have not stated any other conflicts of interest.

\section{REFERENCES}

Allison, M. J., A. L. Baetz, and J. Wiegel. 1984. Alternative pathways for biosynthesis of leucine and other amino acids in Bacteroides ruminicola and Bacteroides fragilis. Appl. Environ. Microbiol. 48:1111-1117. https://doi.org/10.1128/AEM.48.6.1111-1117.1984.

Ankom Technology. 2017. Neutral detergent fiber in feeds-Filter bag technique (for a2000 and a2000i). https://www.ankom.com/ analytical-methods-support/fiber-analyzer-delta.

AOAC (Association of Official Analytical Chemists). 1990. Official Methods of Analysis. 15th ed. AOAC.

Atasoglu, C., and A. Y. Guliye. 2004. Use of stable isotopes to measure de novo synthesis and turnover of amino acid-C and $-\mathrm{N}$ in mixed micro-organisms from the sheep rumen in vitro. Br. J. Nutr. 91:253-266. https://doi.org/10.1079/BJN20031040.

Broudiscou, L. P., A. Offner, and D. Sauvant. 2014. Effects of inoculum source, $\mathrm{pH}$, redox potential and headspace di-hydrogen on rumen in vitro fermentation yields. Animal 8:931-937. https://doi .org/10.1017/S1751731114000640.

Calsamiglia, S., P. W. Cardozo, A. Ferret, and A. Bach. 2008. Changes in rumen microbial fermentation are due to a combined effect of type of diet and pH. J. Anim. Sci. 86:702-711. https://doi.org/10 .2527/jas.2007-0146.

Chaney, A. L., and E. P. Marbach. 1962. Modified reagents for determination of urea and ammonia. Clin. Chem. 8:130-132. https:// doi.org/10.1093/clinchem/8.2.130.

Cummins, K. A., and A. H. Papas. 1985. Effect of isocarbon-4 and isocarbon-5 volatile fatty acids on microbial protein synthesis and dry matter digestibility in vitro. J. Dairy Sci. 68:2588-2595. https: //doi.org/10.3168/jds.S0022-0302(85)81141-3.

Firkins, J. L. 2010. Reconsidering rumen microbial consortia to enhance feed efficiency and reduce environmental impact of ruminant livestock production systems. R. Bras. Zootec. 39:445-457. https://doi.org/10.1590/S1516-35982010001300049

Firkins, J. L., C. M. Fowler, E. Devillard, and B. J. Bequette. 2015. Kinetics of microbial methionine metabolism in continuous cultures administered different methionine sources. J. Dairy Sci. 98:1178-1194. https://doi.org/10.3168/jds.2014-8694.

Firkins, J. L., A. N. Hristov, M. B. Hall, G. A. Varga, and N. R. StPierre. 2006. Integration of ruminal metabolism in dairy cattle. J. Dairy Sci. 89(E. Suppl.):E31-E51. https://doi.org/10.3168/jds .S0022-0302(06)72362-1

Firkins, J. L., Z. Yu, M. Morrison, and M. Morrison. 2007. Ruminal nitrogen metabolism: Perspectives for integration of microbiology and nutrition for dairy. J. Dairy Sci. 90(E. Suppl.):E1-E16.

Fowler, C. M., J. E. Plank, E. Devillard, B. J. Bequette, and J. L. Firkins. 2015. Assessing the ruminal action of the isopropyl ester of 2-hydroxy-4-(methylthio) butanoic acid in continuous and batch cultures of mixed ruminal microbes. J. Dairy Sci. 98:1167-1177. https://doi.org/10.3168/jds.2014-8692. 
Gibson, M. I., P. Y.-T. Chen, and C. L. Drennan. 2016. A structural phylogeny for understanding 2-oxoacid oxidoreductase function. Curr. Opin. Struct. Biol. 41:54-61. https://doi.org/10.1016/j.sbi .2016.05.011.

Gorosito, A. R., J. B. Russell, and P. J. Van Soest. 1985. Effect of carbon- 4 and carbon- 5 volatile fatty acids on digestion of plant cell wall in vitro. J. Dairy Sci. 68:840-847. https://doi.org/10.3168/jds .S0022-0302(85)80901-2.

Gruninger, R. J., G. O. Ribeiro, A. Cameron, and T. A. McAllister. 2019. Invited review: Application of meta-omics to understand the dynamic nature of the rumen microbiome and how it responds to diet in ruminants. Animal 13:1843-1854. https://doi.org/10.1017/ S1751731119000752.

Hackmann, T. J., and J. L. Firkins. 2015a. Electron transport phosphorylation in rumen butyrivibrios: Unprecedented ATP yield for glucose fermentation to butyrate. Front. Microbiol. 6:622. https:// doi.org/10.3389/fmicb.2015.00622.

Hackmann, T. J., and J. L. Firkins. 2015b. Maximizing efficiency of rumen microbial protein production. Front. Microbiol. 6:465. https://doi.org/10.3389/fmicb.2015.00465.

Hino, T., and J. B. Russell. 1985. Effect of reducing-equivalent disposal and NADH/NAD on deamination of amino acids by intact rumen microorganisms and their cell extracts. Appl. Environ. Microbiol. 50:1368-1374. https://doi.org/10.1128/AEM.50.6.1368-1374.1985.

Hoover, W. H. 1986. Chemical factors involved in ruminal fiber digestion. J. Dairy Sci. 69:2755-2766. https://doi.org/10.3168/jds S0022-0302(86)80724-X.

Hristov, A. N., P. Huhtanen, L. M. Rode, S. N. Acharya, and T. A. McAllister. 2001. Comparison of the ruminal metabolism of nitrogen from ${ }^{15} \mathrm{~N}$-labeled alfalfa preserved as hay or as silage. J. Dairy Sci. 84:2738-2750. https://doi.org/10.3168/jds.S0022 $-0302(01) 74728-5$.

Huang, Y., J. P. Marden, C. Julien, and C. Bayourthe. 2018. Redox potential: An intrinsic parameter of the rumen environment. J. Anim. Physiol. Anim. Nutr. (Berl.) 102:393-402. https://doi.org/ 10.1111/.jpn.12855.

Janssen, P. H. 2010. Influence of hydrogen on rumen methane formation and fermentation balances through microbial growth kinetics and fermentation thermodynamics. Anim. Feed Sci. Technol. 160:1-22. https://doi.org/10.1016/j.anifeedsci.2010.07.002.

Kaiser, J. C., and D. E. Heinrichs. 2018. Branching out: Alterations in bacterial physiology and virulence due to branched-chain amino acid deprivation. MBio 9:e01188-18. https://doi.org/10.1128/ mBio.01188-18.

Kajikawa, H., M. Mitsumori, K. Tajima, and M. Kurihara. 2005. Short communication: Amino acids antagonistic to the amino acids inhibitory for growth rate of mixed ruminal bacteria. J. Dairy Sci. 88:2601-2603. https://doi.org/10.3168/jds.S0022-0302(05)72936 -2 .

Kone, P., P. F. Machado, and R. M. Cook. 1989. Effect of the combination of monensin and isoacids on rumen fermentation in vitro. J. Dairy Sci. 72:2767-2771. https://doi.org/10.3168/jds.S0022 $-0302(89) 79420-0$.

Krishtalik, L. I. 2003. pH-dependent redox potential: How to use it correctly in the activation energy analysis. Biochim. Biophys. Acta 1604:13-21. https://doi.org/10.1016/S0005-2728(03)00020-3.

Liu, Q., C. Wang, C. X. Pei, H. Y. Li, Y. X. Wang, S. L. Zhang, Y. L. Zhang, J. P. He, H. Wang, W. Z. Yang, Y. S. Bai, Z. G. Shi, and X. N. Liu. 2014. Effects of isovalerate supplementation on microbial status and rumen enzyme profile in steers fed on corn stover based diet. Livest. Sci. 161:60-68. https://doi.org/10.1016/ j.livsci.2013.12.034.

Lou, J., K. A. Dawson, and H. J. Strobel. 1997. Glycogen formation by the ruminal bacterium Prevotella ruminicola. Appl. Environ. Microbiol. 63:1483-1488. https://doi.org/10.1128/AEM.63.4.1483 $-1488.1997$.

Martínez-Álvaro, M., M. D. Auffret, R. D. Stewart, R. J. Dewhurst, C.-A. Duthie, J. A. Rooke, R. J. Wallace, B. Shih, T. C. Freeman, M. Watson, and R. Roehe. 2020. Identification of complex rumen microbiome interaction within diverse functional niches as mechanisms affecting the variation of methane emissions in bo- vine. Front. Microbiol. 11:659. https://doi.org/10.3389/fmicb.2020 .00659 .

Martinez-Fernandez, G., S. E. Denman, C. Yang, J. Cheung, M. Mitsumori, and C. S. McSweeney. 2016. Methane inhibition alters the microbial community, hydrogen flow, and fermentation response in the rumen of cattle. Front. Microbiol. 7:1122. https://doi.org/10 .3389/fmicb.2016.01122.

Mir, P. S., Z. Mir, and J. A. Robertson. 1986. Effect of branched-chain amino acids or fatty acid supplementation on in vitro digestibility of barley straw or alfalfa hay. Can. J. Anim. Sci. 66:151-156. https: //doi.org/10.4141/cjas86-016.

Mitchell, K. E., B. A. Wenner, C. Lee, M. T. Socha, and J. L. Firkins. 2020. Stimulation of microbial protein synthesis by branched chain volatile fatty acids (BCFA) in dual-flow cultures varying in forage and PUFA concentrations. J. Dairy Sci. 103(Suppl. 1):150. (Abstr.)

Moon, M., and K. L. Anderson. 2001. Eubacterium cellulosolvens alters its membrane protein, lipoprotein, and fatty acid composition in response to growth on cellulose. Anaerobe 7:227-236. https://doi .org/10.1006/anae.2001.0389.

Morais, S., and I. Mizrahi. 2019. Islands in the stream: From individual to communal fiber degradation in the rumen ecosystem. FEMS Microbiol. Rev. 43:362-379. https://doi.org/10.1093/ femsre/fuz007.

Mouriño, F., R. Akkarawongsa, and P. J. Weimer. 2001. Initial pH as a determinant of cellulose digestion rate by mixed ruminal microorganisms in vitro. J. Dairy Sci. 84:848-859. https://doi.org/10 .3168/jds.S0022-0302(01)74543-2.

Nerdahl, M. A., and P. J. Weimer. 2015. Redox mediators modify end product distribution in biomass fermentations by mixed ruminal microbes in vitro. AMB Express 5:130. https://doi.org/10.1186/ s13568-015-0130-7.

Noftsger, S. M., N. R. St-Pierre, S. K. R. Karnati, and J. L. Firkins. 2003. Effects of 2-hydroxy-4-(methylthio) butanoic acid (HMB) on microbial growth in continuous culture. J. Dairy Sci. 86:26292636. https://doi.org/10.3168/jds.S0022-0302(03)73858-2.

Qiu, X., M. L. Eastridge, K. E. Griswold, and J. L. Firkins. 2004. Effects of substrate, passage rate, and $\mathrm{pH}$ in continuous culture on flows of conjugated linoleic acid and trans C18:1. J. Dairy Sci. 87:3473-3479. https://doi.org/10.3168/jds.S0022-0302(04)73482 $-7$.

Roman-Garcia, Y., B. L. Denton, K. E. Mitchell, C. Lee, M. T. Socha, and J. L. Firkins. 2021a. Conditions stimulating neutral detergent fiber degradation by dosing branched-chain volatile fatty acids. I: Comparison with branched-chain amino acids and forage source in ruminal batch cultures. J. Dairy Sci. 104:6739-6755. https://doi .org/10.3168/jds.2020-20054.

Roman-Garcia, Y., K. E. Mitchell, C. Lee, M. Socha, T. Park, B. A. Wenner, and J. L. Firkins. 2021b. Conditions stimulating NDF degradation by dosing branched chain volatile fatty acids. III: Relation with solid passage rate and $\mathrm{pH}$ on prokaryotic fatty acid profile and community in continuous culture. J. Dairy Sci. 104:9868-9885. https://doi.org/10.3168/jds.2021-20336.

Roman-Garcia, Y., R. R. White, and J. L. Firkins. 2016. Meta-analysis of postruminal microbial nitrogen flows in dairy cattle. I. Derivation of equations. J. Dairy Sci. 99:7918-7931. https://doi.org/10 $.3168 /$ jds.2015-10661.

Russell, J. B., and C. J. Sniffen. 1984. Effect of carbon-4 and carbon- 5 volatile fatty acids on growth of mixed rumen bacteria in vitro. J. Dairy Sci. 67:987-994. https://doi.org/10.3168/jds.S0022 -0302(84)81397-1.

Stewart, C. S., H. J. Flint, and M. P. Bryant. 1997. The rumen bacteria. Pages 10-72 in The Rumen Microbial Ecosystem. 2nd ed. C. S. Stewart and P. N. Hobson, ed. Chapman and Hall.

Stumm, W., and M. J. James. 1970. Aquatic Chemistry: An Introduction Emphasizing Chemical Equilibria in Natural Waters. WileyInterscience.

Takahashi, N., and T. Yamada. 2000. Pathways for amino acid metabolism by Prevotella intermedia and Prevotella nigrescens. Oral Microbiol. Immunol. 15:96-102. https://doi.org/10.1034/j.1399 $-302 x .2000 .150205 . x$. 
Terry, S. A., A. Badhan, Y. Wang, A. V. Chaves, and T. A. McAllister. 2019. Fibre digestion by rumen microbiota-A review of recent metagenomic and metatranscriptomic studies. Can. J. Anim. Sci. 99:678-692. https://doi.org/10.1139/cjas-2019-0024.

Ungerfeld, E. M. 2015. Shifts in metabolic hydrogen sinks in the methanogenesis-inhibited ruminal fermentation: A meta-analysis. Front. Microbiol. 6:37. https://doi.org/10.3389/fmicb.2015.00037.

Ungerfeld, E. M. 2018. Inhibition of rumen methanogenesis and ruminant productivity: A meta-analysis. Front. Vet. Sci. 5:113. https:/ /doi.org/10.3389/fvets.2018.00113.

Ungerfeld, E. M., N. L. Urrutia, C. Vásconez-Montúfar, and R. Morales. 2019. Factors associated with the content of mammary-synthesized fatty acids in milk fat: A meta-analysis. J. Dairy Sci. 102:4105-4117. https://doi.org/10.3168/jds.2018-15157.

Van Kessel, J. A. S., and J. B. Russell. 1996. The effect of pH on ruminal methanogenesis. FEMS Microbiol. Ecol. 20:205-210. https:/ /doi.org/10.1016/0168-6496(96)00030-X.

Van Soest, P. J., J. B. Robertson, and B. A. Lewis. 1991. Methods for dietary fiber, neutral detergent fiber, and nonstarch polysaccharides in relation to animal nutrition. J. Dairy Sci. 74:3583-3597. https://doi.org/10.3168/jds.S0022-0302(91)78551-2.

Wang, C., Q. Liu, Y. L. Zhang, C. X. Pei, S. L. Zhang, Y. X. Wang, W. Z. Yang, Y. S. Bai, Z. G. Shi, and X. N. Liu. 2015. Effects of isobutyrate supplementation on ruminal microflora, rumen enzyme activities and methane emissions in Simmental steers. J. Anim. Physiol. Anim. Nutr. (Berl.) 99:123-131. https://doi.org/10.1111/ jpn.12191.

Ward, D. E., C. C. van der Weijden, M. J. van der Merwe, H. V. Westerhoff, A. Claiborne, and J. L. Snoep. 2000. Branched-chain $\alpha$-keto acid catabolism via the gene products of the $b k d$ operon in Enterococcus faecalis: A new, secreted metabolite serving as a temporary redox sink. J. Bacteriol. 182:3239-3246. https://doi.org/10 $.1128 / J B .182 .11 .3239-3246.2000$.
Weller, R. A., and A. F. Pilgrim. 1974. Passage of protozoa and volatile fatty acids from the rumen of the sheep and from a continuous in vitro fermentation system. Br. J. Nutr. 32:341-351. https://doi .org/10.1079/BJN19740087.

Wenner, B. A., J. de Souza, F. Batistel, T. J. Hackmann, Z. Yu, and J. L. Firkins. 2017. Association of aqueous hydrogen concentration with methane production in continuous cultures modulated to vary $\mathrm{pH}$ and solids passage rate. J. Dairy Sci. 100:5378-5389 https://doi.org/10.3168/jds.2016-12332.

Wenner, B. A., B. K. Wagner, N. R. St-Pierre, Z. T. Yu, and J. L. Firkins. 2020. Inhibition of methanogenesis by nitrate, with or without defaunation, in continuous culture. J. Dairy Sci. 103:71247140. https://doi.org/10.3168/jds.2020-18325.

Zhang, Y. L., Q. Liu, C. Wang, C. X. Pei, H. Y. Li, Y. X. Wang, W. Z. Yang, Y. S. Bai, Z. G. Shi, and X. N. Liu. 2015. Effects of supplementation of Simmental steers with 2-methylbutyrate on rumen microflora, enzyme activities and methane production. Anim. Feed Sci. Technol. 199:84-92. https://doi.org/10.1016/j.anifeedsci .2014.11.003.

\section{ORCIDS}

Y. Roman-Garcia @ https://orcid.org/0000-0001-8181-2470

K. E. Mitchell ๑ https://orcid.org/0000-0002-9769-3960

B. L. Denton (ํ) https://orcid.org/0000-0002-2969-2915

C. Lee $\odot$ https://orcid.org/0000-0002-4522-1232

M. T. Socha @ https://orcid.org/0000-0002-0227-6591

B. A. Wenner $\odot$ https://orcid.org/0000-0002-2333-1297

J. L. Firkins (ㄴ) https://orcid.org/0000-0003-3518-1940 